\title{
Storage of soybean seeds treated with chemicals
}

\section{Armazenamento de sementes de soja tratadas com produtos químicos}

\author{
Isneider Luiz Silva $^{1 *}$; Fernando Ribeiro Teles de Camargo ${ }^{1}$; Raniele Tadeu \\ Guimarães de Souza ${ }^{1}$; Itamar Rosa Teixeira ${ }^{2}$; Hamilton Kikuti ${ }^{3}$
}

\begin{abstract}
To treat seed lots during the beneficiation process industrial seed treatment (TIS) has been used on seedlings. However, the actual TIS influence on the physiological quality of soybeans throughout storage is not yet known. The objective of this work was to evaluate the effects of TIS on the physiological quality of seeds of soybean cultivars during storage. Three soybean cultivars (M7110 IPRO, RR-8473RSF, M7739 IPRO) were subjected to four chemical treatment combinations (TICtreated fungicide / insecticide): T1 - control; T2 - fungicide (Derosal Plus ${ }^{\circledR}$ - 200mL); T3 - insecticide $($ Cruiser $\mathbb{B}-500 \mathrm{~mL})$; T4 - a mixture of fungicide and insecticide products metalaxyl + thiabendazole + fludioxonil (MaximAdvanced - $200 \mathrm{~mL}$ ) and thiamethoxam insecticide (Cruiser $350 \mathrm{FS}-500 \mathrm{~mL}$ ). The samples were stored for a total of six months, with evaluation before storage and monthly throughout the storage period $(0,30,60,90,120,150$ and 180 days). The seeds were stored in a cold chamber regulated at $12 \pm 2{ }^{\circ} \mathrm{C}$ and a relative humidity of $45 \pm 2 \%$. In addition to determining the water content, the following germination and vigor tests were performed: first count, seedling length, seedling dry mass and accelerated aging. A completely randomized design was used, in a $3 \times 4 \times 7$ factorial scheme, with four replications. The data were initiallysubjected to analysis of variance, and later discriminated by the Tukey test $(\mathrm{p}<0.05)$ (cultivars and chemical products) and regression (storage period). The work concludes that the use of insecticide favored the length of seedlings in cultivar RR-8473 RSF. Chemicals affected the quality and vigor of seeds in all studied cultivars. Soybean seeds can be stored with chemical treatment for commercial purposes for up to 60 days.
\end{abstract}

Key words: Glycine max [L.] Merrill. Cultivars. Seed quality. Industrial seed treatment.

\section{Resumo}

Com a finalidade de tratar lotes de sementes durante o processo de beneficiamento as sementeiras passam a utilizar o tratamento industrial de sementes (TIS). Todavia, não se sabe ainda qual a real influência TIS sobre a qualidade fisiológica de sementes de soja ao longo do armazenamento. Este trabalho teve por objetivo avaliar os efeitos do tratamento com produtos químicos oriundos do TIS sobre a qualidade fisiológica de sementes de cultivares de soja durante o armazenamento. Três cultivares de soja (M7110 IPRO; RR- 8473RSF, M7739 IPRO) foram submetidas a quatro combinações de tratamentos com defensivos químicos (fungicida/inseticida) aplicados via TIS: \{T1- testemunha; T2-

\footnotetext{
1 Discentes do Curso de Mestrado do Programa de Pós-Graduação em Engenharia Agrícola, Departamento de Engenharia Agrícola, Universidade Estadual de Goiás, UEG, Anápolis, GO, Brasil. E-mail: isneider.luiz@gmail.com; fernando_camargo81@hotmail. com; raniele.souza1@gmail.com

2 Prof., Departamento de Engenharia Agrícola, UEG, Anápolis, GO, Brasil. E-mail: itamar.texeira@ueg.br

3 Prof., Departamento de Agronomia, Universidade Federal de Uberlândia, UFU, Uberlândia, MG, Brasil. E-mail: hkikuti@iciag. ufu.br

* Author for correspondence
} 
fungicida (Derosal Plus ${ }^{\circledR}$ - 200mL); T3- inseticida (Cruiser ${ }^{\circledR}$ - 500mL); T4- mistura dos produtos fungicida e inseticida $\}$, e armazenadas por seis meses, com avaliações mensais $(0 ; 30 ; 60 ; 90 ; 120$; 150 e 180 dias). As sementes foram armazenadas em câmara fria regulada a $12 \pm 2{ }^{\circ} \mathrm{C}$ e umidade relativa de $\pm 45 \%$. Além da determinação do teor de água, foram realizadas teste de germinação e vigor : primeira contagem, comprimento de plântula, massa seca de plântula e envelhecimento acelerado. Foi empregado o delineamento inteiramente casualizado, em esquema fatorial $3 \times 4 \times 7$, com quatro repetições.Os dados obtidos foram submetidos à análise de variância inicialmente, e posteriormente discriminados pelo teste de Tukey $(p<0,05)$ (cultivares e produtos químicos) e regressão (período de armazenamento). Conclui-se com o trabalho que o uso de inseticida favoreceu o comprimento de plântulas na cultivar RR-8473 RSF. Produtos químicos prejudicaram a qualidade e o vigor de sementes em todas as cultivares estudadas. As sementes de soja podem ser mantidas armazenadas com tratamento químico para fins comerciais até os 60 dias.

Palavras-chave: Glycine max [L.] Merrill. Cultivares. Qualidade de sementes. Tratamento industrial de sementes.

\section{Introduction}

The soybean [Glycine max (L.) Merrill] is the largest oilseed produced in the world. Brazil is the second largest producer, surpassed only by the USA. In the 2017/18 harvest, the Brazilian production was 113.02 million tons of grain, with an average yield of $3.225 \mathrm{~kg} \mathrm{ha}^{-1}$ (CONAB, 2018). However, Brazil still has a large agricultural frontier, which allows for the expansion of the crop, making it possible to surpass the USA by 2020 (FREITAS, 2011). For this to become a reality, important bottlenecks must be overcome such as the attacks of pests and disease, which have contributed to reduced levels of productivity each year.

The use of seed lots associated with the use of seed treatment may become the most viable way to overcome this problem (LUDWIG et al., 2011). Seed treatment consists of a technique that aims to apply products and substances that maintain or improve performance, allowing the cultures to express their full genetic potential under field conditions. This approach favors the emergence of seedlings through pathogen control, as well as being an inexpensive and viable alternative to reduce the damage caused to the seeds by these factors (CORADI et al., 2015; CUNHA et al., 2015).

Seed treatment includes the application of compounds that may have a bioactive effect, affecting plant metabolism and increasing crop yield (LAUXEN et al., 2010; MENTEN et al., 2010; BALARDIN et al., 2011). These compounds are used before sowing or in the sequential phase, using specific machines. However, with the technological advances of Brazilian agriculture, sowing companies are adopting new techniques that maximize crop yields. For example, an industrial process of seed treatment has been created, called seed industrial treatment (TIS), in which many seeds are treated during the processing phase and then bagged and stored until sowing (DAN et al., 2013).

This new technique can be used to develop new formulations containing fungicides, insecticides, nematicides, biological products, inoculants, stimulants, and micronutrients in the same treatment (DAN et al., 2013) and can maximize product efficiency, help protect the applicator and avoid environmental contamination. However, anticipation of the chemical treatment may reduce the physiological quality of the seeds during packaging, due to the possibility of phytotoxic effects that some active ingredients of the products may have on the seeds. This phytotoxic effect reduces germination, vigor and emergence of seedlings and impairs plant establishment and crop productivity (MAVAIEI, 2014).

Most of the studies have conflicting results regarding the accomplishment of the treatment of seeds following conditioning, such as the work 
conducted by Ludwig et al. (2011), who verified a decrease in the germination percentage of soybean seeds treated with fludioxonil + metalaxyl (Maxim) and the insecticide thiamethoxam (Cruiser), after storage for up to 180 days. Additionally, Dan et al. (2010) observed a reduction in the physiological quality of soybean seeds treated with the insecticides carbofuran (Furadan) and acephate (Orthene) from 45 days of storage onwards. On the other hand, Avelar et al. (2011), analyzed the effect of using fludioxonil + metalaxyl (Maxim) and thiamethoxam (Cruiser), an insecticide with micronutrients and other polymers, on the storage of soybean seeds and found that the products maintained good seed quality during a period of 90 days of storage. Furthermore, the study yielded more vigorous plants when compared to the control. These results are also consistent with a study by Mbofung et al. (2013), in which soybean seeds were treated with the fungicides fludioxonil (Maxim) + metalaxyl (Mefenoxam) and the insecticide thiamethoxam (Actara) and stored with different water contents for 24 months. This study verified that the interactions of seed treatments did not interfere with germination, seedling length and even generated more vigorous plants in an emergency sand test.

Apparently the most toxic effects of seeds are promoted by treatment involving the use of insecticides in isolation but also in mixtures with other chemicals such as fungicides, micronutrients, biostimulants, etc. Castro et al. (2008) evaluated soybean seed treatments with insecticides (thiamethoxam) and biostimulants (root growth promoter) and found that aldicarb insecticide, even at the dose used, impaired soybean seed vigor and germination. Seed application with insecticides and biostimulants provide greater root growth of soybean plants.

In a recent study conducted by Binsfeld et al. (2014), in which the mixture of the insecticide thiamethoxam(Cruiser), anutrientcomplexinvolving macro- and micronutrients (DimicronTMSp) and a biostimulant containing indolebutyric acid, kinetin and gibberellic acid (Stimulate ${ }^{\circledR}$ ) was tested, it was shown that the treatment with the best result in the initial performance of soybean seeds was the nutrient complex, followed by the plant growth regulator with a biostimulating effect. The insecticide had a negative effect on seed germination and on seedling development.

The application of chemical products (insecticides/fungicides) generally promotes increased seed performance in the field, but their effect on seed quality during storage requires further study (SEGALIN et al., 2013). In addition, most of the investigations have involved mixtures of several products in the formulations, making it impossible to know the isolated effect of the tested product, and thus making it impossible to draw reliable conclusions.

Knowing that seed treatment has presently become an integrated practice in agricultural production, mainly in the soybean crop, the present study aims to evaluate the physiological quality of soybean seeds that were treated with chemical products and stored for 180 days.

\section{Material and Methods}

The soybean seeds used in this study were produced in the agricultural crop of 2016/2017, classified as category $\mathrm{C} 1$, passed through a 6.5$\mathrm{mm}$ sieve, and exhibited a $10 \pm 2 \%$ water content. After data collection and processing, seed lots were brought to the Laboratory of Drying and Storage of Vegetable Products of the State University of Goiás, CâmpusAnápolis (CCET), Brazil, to be subjected to the intended treatments.

For the treatment with chemical products, the seeds of each soybean cultivar were placed in plastic bags, according to each specific treatment. The doses of the products used on the seeds were applied inside the plastic bag. Subsequently, the seed and chemical contents were stirred until homogenized. 
The experiment was a completely randomized design, in a $3 \times 4 \times 7$ factorial scheme (three cultivars $\mathrm{x}$ chemical treatments $\mathrm{x}$ evaluation periods), with four replications. The treatments consisted of seeds from three soybean cultivars (M-7110 IPRO, RR-8473 RSF, M-7739 IPRO), with or without fungicide / insecticide applied in the TIS: (T1 control; T2 - fungicide metalaxyl + thiabendazole + fludioxonil (Maxim Advanced - 200mL); T3 - insecticide thiamethoxam (Cruiser 350 FS $500 \mathrm{~mL}$ ); T4 - a mixture of fungicide and insecticide products metalaxyl + thiabendazole + fludioxonil (Maxim Advanced - 200mL) and thiamethoxam insecticide (Cruiser 350 FS - 500mL).the samples were stored for a total of six months, with evaluation before storage and monthly throughout the storage period $(0,30,60,90,120,150$ and 180 days. The doses in milliliters used are recommended by the manufacturer for $100 \mathrm{~kg}$ of soybean seeds.

After subjection to these treatments, the soybean seed lots were placed in multifolium kraft paper packaging, which is the most commonly used packaging by seed companies such as Crop (CUNHA et al., 2015). They were then separated according to each chemical treatment and the period for which they were stored, and subsequently stored in a cold room regulated at $12^{\circ} \mathrm{C} \pm 2$ and $45 \% \pm 2$ RH. After each monthly evaluation of the quality tests, the soybean seeds, along with the packaging, were discarded. The determination of the water content and the following physiological quality tests of the soybean seeds were performed before storage and in each period of germination: first count, seedling length, seedling dry mass and accelerated aging. The water content on a wet basis (bu) was determined by the greenhouse method, with forced ventilation at $105 \pm 3^{\circ} \mathrm{C}$ for 24 hours, according to the Rules for Seed Analysis - RAS (BRASIL, 2009), with modification in the use of three replicates.

Germination test: Four replicates of 50 seeds per treatment were used to germinate on germitest paper in roll form. The seeds were moistened with an amount of deionized water equivalent to 2.5 times the dry paper weight and placed in a regulated germinator (Biomatic TIC-175) at $25^{\circ} \mathrm{C}$ (BRASIL, 2009). At the end of the eighth day, the number of normal seedlings was evaluated. The results were expressed as a percentage.

First germination count: This count was performed in conjunction with the germination test, and the normal seedling evaluation was quantified on the fifth day of the test assembly. The results were also expressed as a percentage of normal seedlings.

Seedling length: Four replicates of 10 seeds from each treatment were distributed in germitest paper rolls moistened with deionized water in a ratio of 2.5:1 ( $\mathrm{mL}$ of distilled water per $\mathrm{g}$ dry paper) and kept in a germinator at $25{ }^{\circ} \mathrm{C}$ for eight days (NAKAGAWA, 1999). A line was drawn in a longitudinal direction on the upper third of the wet germ paper, in which the seeds were placed, to direct the micropyle downwards. The length of the seedlings that were considered normal (BRASIL, 2009) was determined at the end of the eighth day, using a millimeter ruler.

Dry mass of seedlings: In this evaluation, the normal seedlings from the seedling length test were used. Each sample was packed in paper bags and forced into the oven, with forced air circulation maintained at $80{ }^{\circ} \mathrm{C}$ for 24 hours (NAKAGAWA, 1999). After this period, the bags were removed and placed in a desiccator, and then each repetition was weighed on a digital scale with an accuracy of $0.001 \mathrm{~g}$. The results were expressed as $\mathrm{mg}$ seedling ${ }^{-1}$.

Accelerated aging: The methodology is described by Silva et al. (2010). A single layer of seeds was placed on a metal screen attached to a gerbox plastic box containing $40 \mathrm{~mL}$ of water in the bottom. The boxes were capped in order to obtain $100 \% \mathrm{RH}$ in the interior and were kept in a germination chamber at $42{ }^{\circ} \mathrm{C}$ for 48 hours. After this period, four subsamples of 50 seeds were allowed to germinate, following the method described for the germination test. The results obtained on the fifth day were expressed as a percentage. 
After the tests, the data were initially subjected to analysis of variance $(\mathrm{p}<0.05)$, and when applicable, the regression test was applied. The Sisvar 5.6 program (FERREIRA, 2014) was used in the data analysis.

\section{Results and Discussion}

Significance of the triple interaction between the factors, soybean cultivars, chemical products and storage periods for all applied tests was verified.
The highest values (Figure 1) of normal seedling percentages were verified by inoculating M-7110 IPRO in the absence of chemical products for up to 60 days of storage, showing that the seed treatment with chemicals promoted damage to seed viability from the initial period of chemical treatment. However, the importance of performing the technique for the control of initial pests and soybean disease, whether or not associated with conventional or TIS treatment, is unquestionable.

Figure 1. Percent of germination of soybean seeds treated with chemical products throughout storage.

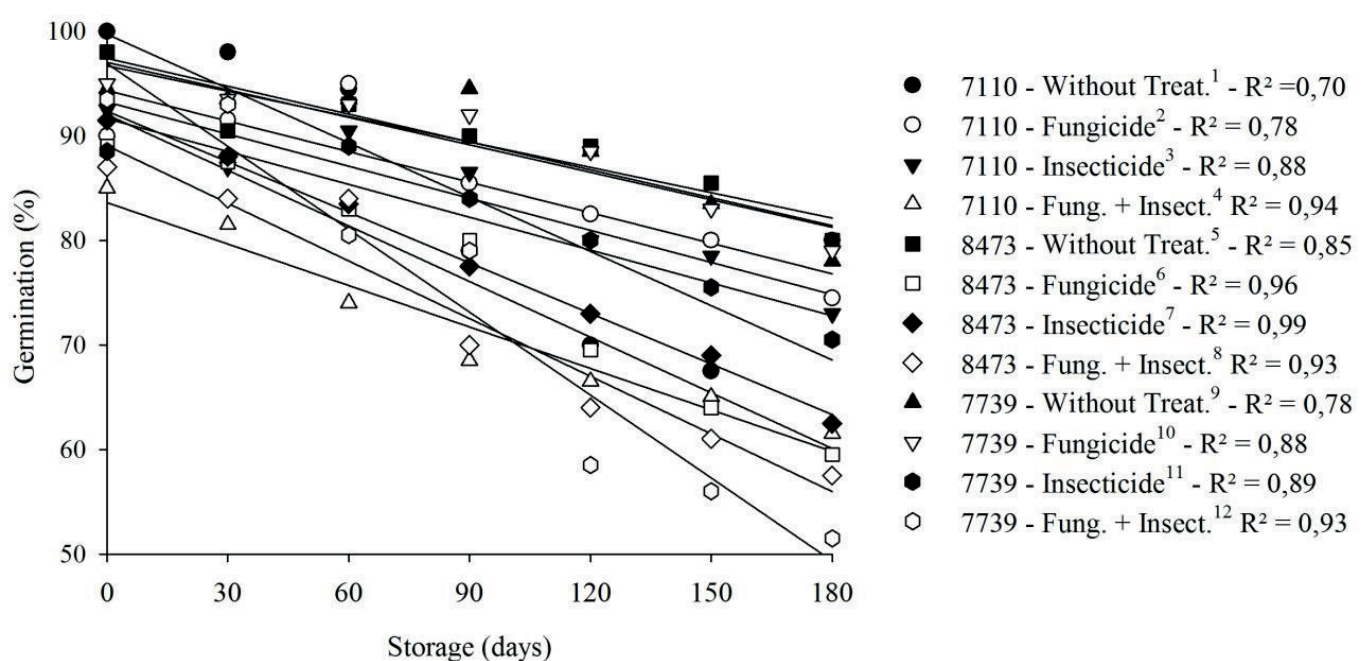

Without Treatment $=$ absence of chemicals; Fungicide $=$ Metalaxil + Tiabendazol + Fluxonidil; Insecticide $=$ Tiametoxam;

Fung. + Insect. $=$ Metalaxil + Tiabendazol + Fluxonidil + Tiametoxam

$1-y=-0,1732 x+99,732 ; 2-y=-0,0976 x+94,357 ; 3-y=-0,1024 x+93,214 ; 4-y=-0,1321 x+83,607 ; 5-y=-0,081 x+96,714$

$6-y=-0,1774 x+92,036 ; 7-y=-0,1613 x+92,375 ; 8-y=-0,1839 x+89,054 ; 9-y=-0,0887 x+97,411 ; 110-y=-0,0875 x+97,018$

$11-y=-0,1048 x+91,643 ; 12-y=-0,2643 x+96,929$.

From the 90-day storage period, the best germination response was from the cultivar M-7739 IPRO, which showed $94.5 \%$ germination for the control, which did not receive treatment with chemicals until the end of the storage (Figure 1).

As for the TIS application of chemical products to soybean seeds, for all cultivars tested, neither the addition of metalaxyl + thiabendazole + fludioxonil (fungicide), thiamethoxam (insecticide)northe combination of both fungicide and insecticide was beneficial for germination, after chemical treatment and throughout the storage period (Figure 1).
The use of chemicals did notaffect the germination of the soybean seeds until 60 days of storage, to the point of being below the recommended percentage for its commercialization, which is $80 \%$ (BRASIL, 2009).

The use of fungicide-based products, such as the one used in this study, can maintain the physiological quality of soybean seeds, corroborating the results of Avelar et al. (2011), who did not find a decrease in the percentage of germination when using fungicide products in the treatment of soybean seeds. 
Regarding the use of insecticides, Dan et al. (2013) found that in the chemical treatment of soybean seeds, the use of some insecticides such as thiodicarb and thiamethoxam, which were also used in this study, impairs the maintenance of the physiological quality of soybean seeds throughout storage, especially in a 30-day period of storage. It was found that they also have a more harmful effect on seeds compared to fungicide products.

In this situation, the process of physiological deterioration of the seed throughout the storage after the treatments hould be monitored to avoid a decrease in the percentage not acceptable for commercialization of seeds in the market, which is currently higher than 80-85\% (FERREIRA, 2016).

The fact that chemical application has yielded lower germination averages in relation to the control can be explained in some cases (depending on the morphology of the chosen cultivars, the application form and the storage time of the seeds)by the fact that these products interfere in seed quality. This can be explained by their action within the seeds, in which they may generate rearrangements in chemical structure due to their systemic actions.

The percentage of normal seedlings obtained in the first count test of soybean seeds (Figure 2) showed a similar behavior to that verified in the germination test. Seeds of cultivar M-7110 IPRO, without addition of chemicals, showed the highest average seedlings after up to 120 days of storage. At 150 and 180 days, the best result was found for cultivar M-7739, without addition of chemical treatment. In all storage periods, RR-8473 presented the worst means in relation to the other cultivars.

Figure 2. Germination values of the first count test of the soybean seeds treated with chemical products throughout storage.
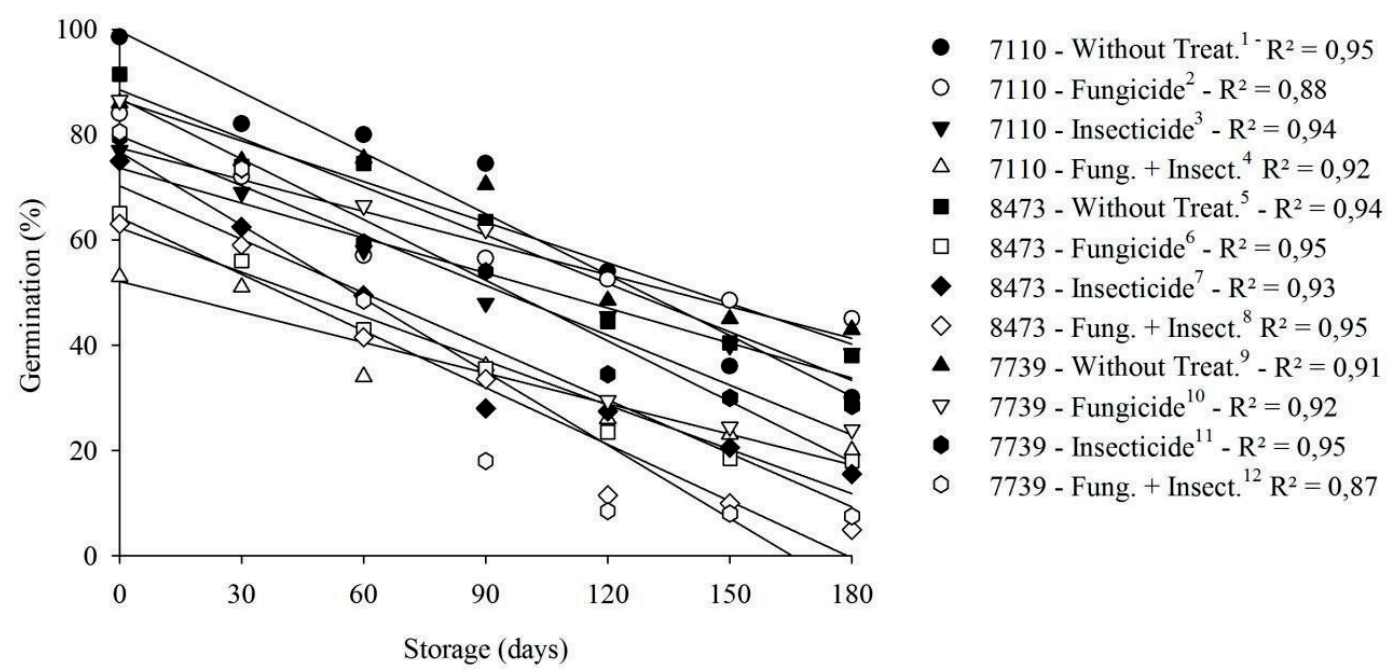

Without Treatment $=$ absence of chemicals; Fungicide $=$ Metalaxil + Tiabendazol + Fluxonidil; Insecticide $=$ Tiametoxam Fung + Insect. $=$ Metalaxil + Tiabendazol + Fluxonidil + Tiametoxam

$1-y=-0,3851 x+99,661 ; 2-y=-0,2006 x+77,411 ; 3-y=-0,2214 x+73,643 ; 4-y=-0,194 x+52,179 ; 5-y=-0,3065 x+88,518$

$6-y=-0,2804 x+62,304 ; 7-y=-0,3387 x+70,268 ; 8-y=-0,3595 x+64,286 ; 9-y=-0,2571 x+86,50 ; 10-y=-0,3839 x+86,911$ $11-y=-0,3155 x+79,75 ; 12-y=-0,4643 x+76,714$ 
The average values of germination of the first count are close to those obtained in the work done by Ferreira (2016), in that the only the best averages in the analyses performed before storage and with 30 days of storage were considered for commercialization; that is, in the initial moments of the experiment,.

The addition of chemicals metalaxyl + thiabendazole + fludioxonil (fungicide) and thiamethoxam (insecticide), alone or combined, impaired the vigor of the soybean cultivars for all storage periods. In addition, treatments with metalaxyl + thiabendazole + fludioxonil (fungicide) combined with thiamethoxam (insecticide) always presented the worst means compared to the other treatments throughout the storage period (Figure 2).

The effects of chemicals on the vigor of soybean seeds at the first count were similar to those found in the germination test, in which the seeds subjected to chemical treatment with fungicide (metalaxyl + thiabendazole + fludioxonil) had a higher percentage of normal seedlings compared to those treated with insecticide (thiamethoxam). The worst results were obtained with the combination of these two products. Thus, these results corroborate data from the germination test, in which it was possible to verify that the isolated use of metalaxyl + thiabendazole + fludioxonil (fungicide) and thiamethoxam (insecticide) products in soybean seeds until 60 days of storage can occur, without prejudice to the physiological quality of soybean seeds.

When studying the effect of thiodicarb and thiamethoxamon the quality of soybean seeds during storage, Dan et al. (2013) concluded that seed treatment with these products promoted negative effects under germination and the first counting of germination during storage for a period of 30 days, disagreeing in part with the results obtained in the research.
Regarding the combination of metalaxyl + thiabendazole + fludioxonil and thiamethoxam, also used in this study, Camargo et al. (2017) verified that in soybean seeds, the first germination count is greatly impaired in the initial period of evaluation.

The fact that this could explain why the combined chemical treatments of metalaxyl + thiabendazole + fludioxonil (fungicide) and thiamethoxam (insecticide) presented the worst results of germination and first count of normal seedlings, corroborates the data of Brzezinski et al. (2017), who verified that the excess use of chemical syrup volumes can cause phytoxicity in the soybean seeds, also preventing the process of respiration of the seeds. Therefore, they recommended the use of only $300 \mathrm{~mL}$ of products on the mass of seeds.

The treatments of soybean seeds with chemical products influenced the results of the aging test, as occurred in the germination and first count tests. The M-7110 IPRO cultivar, without the addition of chemicals, showed the highest percentage of normal seedlings (68\%), for up to 60 days of storage (Figure 3).

The values related to the percentage of normal seedlings obtained in the accelerated aging test tended to zero from the 90 days of storage and had seeds without germination after 120 days of storage(considered dead seeds).

The results of the accelerated aging test are compatible with those found in the work of Cunha et al. (2015), in which chemicals such as thiamethoxam, abamectin + thiamethoxam + fludioxonil, imidacloprid + thiodicarb, and the same chemicals used in this study, contributed to the increased deterioration of treated seeds before and after storage. 
Figure 3. Germination values of the accelerated aging test of soybean seeds treated with chemical products throughout storage.

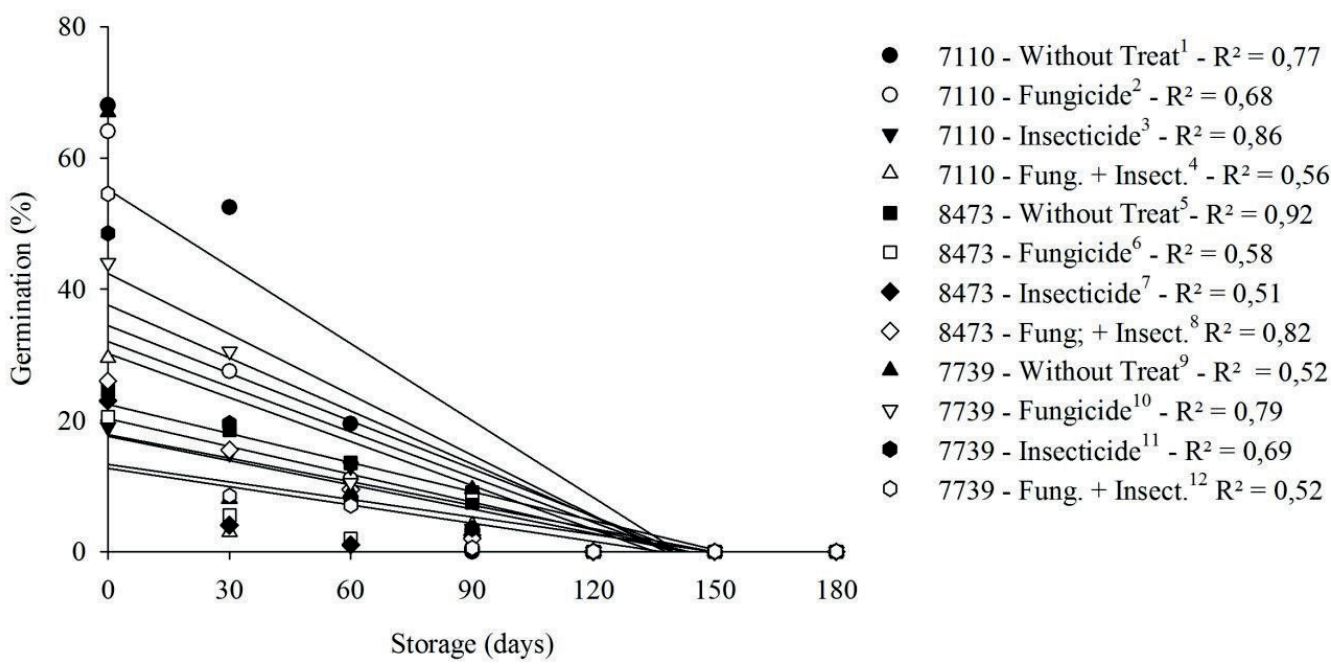

\begin{abstract}
Without Treatment $=$ absence of chemicals; Fungicide $=$ Metalaxil + Tiabendazol + Fluxonidil; Insecticide $=$ Tiametoxam Fung. + Insect. $=$ Metalaxil + Tiabendazol + Fluxonidil + Tiametoxam.

$1-y=-0,3911 x+55,196 ; 2-y=-0,3071 x+42,357 ; 3-y=-0,119 x+17,786 ; 4-y=-0,1232 x+17,589 ; 5-y=-0,1476 x+22,429$ $6-y=-0,0887 x+13,268 ; 7-y=-0,0929 x+12,714 ; 8-y=-0,1411 x+20,268 ; 9-y=-0,269 x+37,571 ; 10-y=-0,2423 x+34,446$ $11-y=-0,2292 x+31,982 ; 12-y=-0,2232 x+30,161$.
\end{abstract}

In their study of soybean seeds treated and stored for 60 days, Vieira et al. (2013) state that the use of chemicals, regardless of the active ingredient, tends to accelerate the process of seed deterioration, which can be aggravated when seeds are already subject to some stress, such as the accelerated aging test. This is because the chemicals tend to generate more phytotoxicity in the seeds or seedlings in this type of environment.

Despite the reduction of germination percentages of soybean seeds, Mbofung et al. (2013) and Conceição et al. (2016) found that the fungicide thiram and the insecticides imidacloprid and thiodicarb controlled insects and fungi in soybean seeds during storage for 120 days, and did not affect their physiological quality. Seedling length values were higher $(22 \mathrm{~cm})$ in the seeds belonging to the cultivar RR-8473 treated with thiamethoxam, during the entire storage period (Figure 4), than in the germination, first count and aging tests.

The fact that the chemical was beneficial to the seedling length can be attributed to the genetic characteristics of the seeds of the soybean cultivars, as well as to the use of thiamethoxam, because it has a bioactive action in addition to controlling pathogens; therefore, it generates increments in agronomic characteristics of the seedlings as the size of the radicle, through alterations of the mechanisms that produce vegetal hormones such as auxins (DAN et al., 2013).

Thus, the results obtained for seedling length corroborate the hypotheses cited above, as well as the conclusions of the study by Piccini et al. (2013), in which they verified that the applications of the insecticide thiamethoxam and the fungicide Abamectin promoted length increases of soybean seedlings, throughout a storage period of 180 days.

The seeds of the investigated cultivars submitted to chemical treatments as well as those of the control presented a reduction in viability and vigor throughout the storage periods (Figure 4), a fact that is related to the physiological deterioration of soybean seeds, as detected in the first counting and accelerated aging germination tests. 
Figure 4. Seedling length values of soybean seeds treated with chemical products throughout storage.

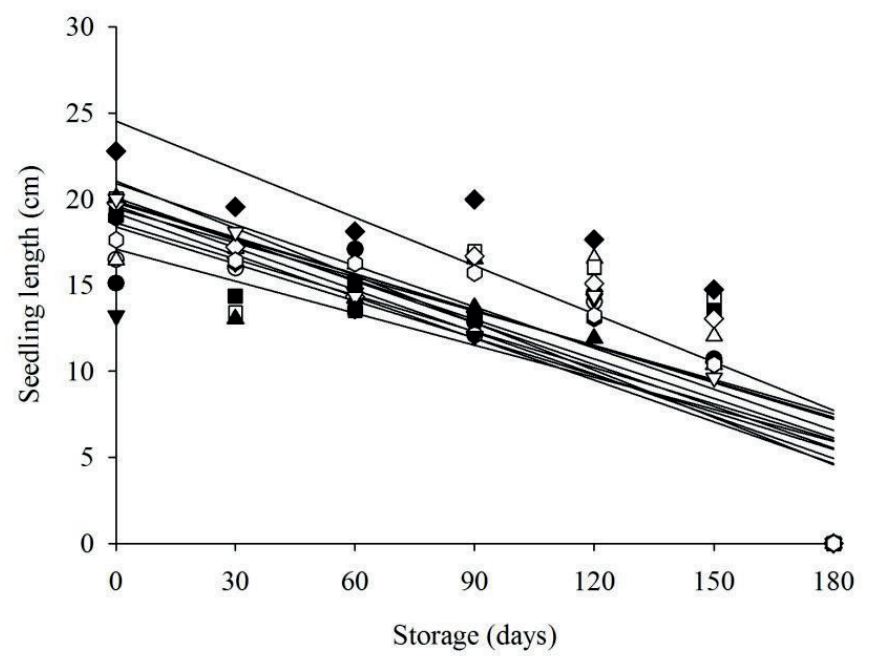

- $\quad 7110$ - Without Treat. ${ }^{1}-\mathrm{R}^{2}=0,60$

○ 7110 - Fungicide ${ }^{2}-\mathrm{R}^{2}=0,67$

v 7110 - Insecticide ${ }^{3}-\mathrm{R}^{2}=0,64$

$\triangle \quad 7110$ - Fung + Insect. ${ }^{4} \mathrm{R}^{2}=0,63$

- 8473 - Without Treat. ${ }^{5}-\mathrm{R}^{2}=0,55$

8473 - Fungicide ${ }^{6}-\mathrm{R}^{2}=0,64$

- 8473 - Insecticide ${ }^{7}-\mathrm{R}^{2}=0,64$

$\diamond \quad 8473-$ Fung + Insect. $^{8} \mathrm{R}^{2}=0,69$

\ 7739 - Without Treat. ${ }^{9}-\mathrm{R}^{2}=0,74$

$\nabla \quad 7739$ - Fungicide $^{10}-\mathrm{R}^{2}=0,81$

- 7739 - Insecticide ${ }^{11}-\mathrm{R}^{2}=0,77$

○ 7739 - Fung + Insect. ${ }^{12} \mathrm{R}^{2}=0,72$

Without Treatment $=$ absence of chemicals; Fungicide $=$ Metalaxil + Tiabendazol + Fluxonidil; Insecticide $=$ Tiametoxam Fung. + Insect. $=$ Metalaxil + Tiabendazol + Fluxonidil + Tiametoxam

$1-y=-0,0701 x+18,614 ; 2-y=-0,0717 x+18,375 ; 3-y=-0,062 x+17,09 ; 4-y=-0,0704 x+19,878 ; 5-y=-0,0691 x+19,77$

$6-y=-0,0662 x+19,424 ; 7-y=-0,0934 x+24,516 ; 8-y=-0,0797 x+20,899 ; 9-y=-0,0808 x+19,171 ; 10-y=-0,0916 x+21,041$ $11-y=-0,0815 x+19,603 ; 12-y=-0,0808 x+20,076$.

At 180 days of storage, almost all the seeds died, thus not achieving germination for the length of seedlings.

Seed treatment with thiamethoxam showed higher results than in the other treatments during all storage periods, followed by the combined treatments of insecticide + fungicide, fungicide and control.

Additionally, the results found by Ludwig et al. (2015) showed that chemical treatments of soybean seeds with the insecticides thiamethoxam and fipronil benefited the seedling length during a storage period of 120 days. Camargo et al. (2017), when using a combination of the active ingredients metalaxyl + thiabendazole + fludioxonil + thiamethoxam, verified an increase in the length of soybean seedlings in relation to seeds that did not receive chemical treatment, thus agreeing with the results of the present research.

In relation to the dry mass of seedlings produced, there was a significant difference between cultivars and chemical products (Figure 5), only for treatments without conditioning (time zero) and 120 days of storage.

After treatment with chemical products, but without conditioning, the highest seedling dry mass weights were verified for the cultivars M-7739 and RR-8473, when they were treated with chemical products, metalaxyl + thiabendazole + fludioxonil and thiamethoxam, separately. However, at 120 days of storage, treatment with the combination of metalaxyl + thiabendazole + fludioxonil and thiamethoxam provided the lowest seedling dry mass means of cultivar M-7739.

The results of the seedling dry mass and seedling length tests are discordant. The occurrence of these results is due to the chemical products based on the insecticide thiamethoxam, which promotes cell growth and expansion; however, this expansion is not associated with the increase of dry mass in the soybean seedlings, but benefits the increase of dry mass and seedling length when compared to the untreated seeds. 
Figure 5. Dry seedling mass values of soybean seeds treated with chemical products throughout storage.

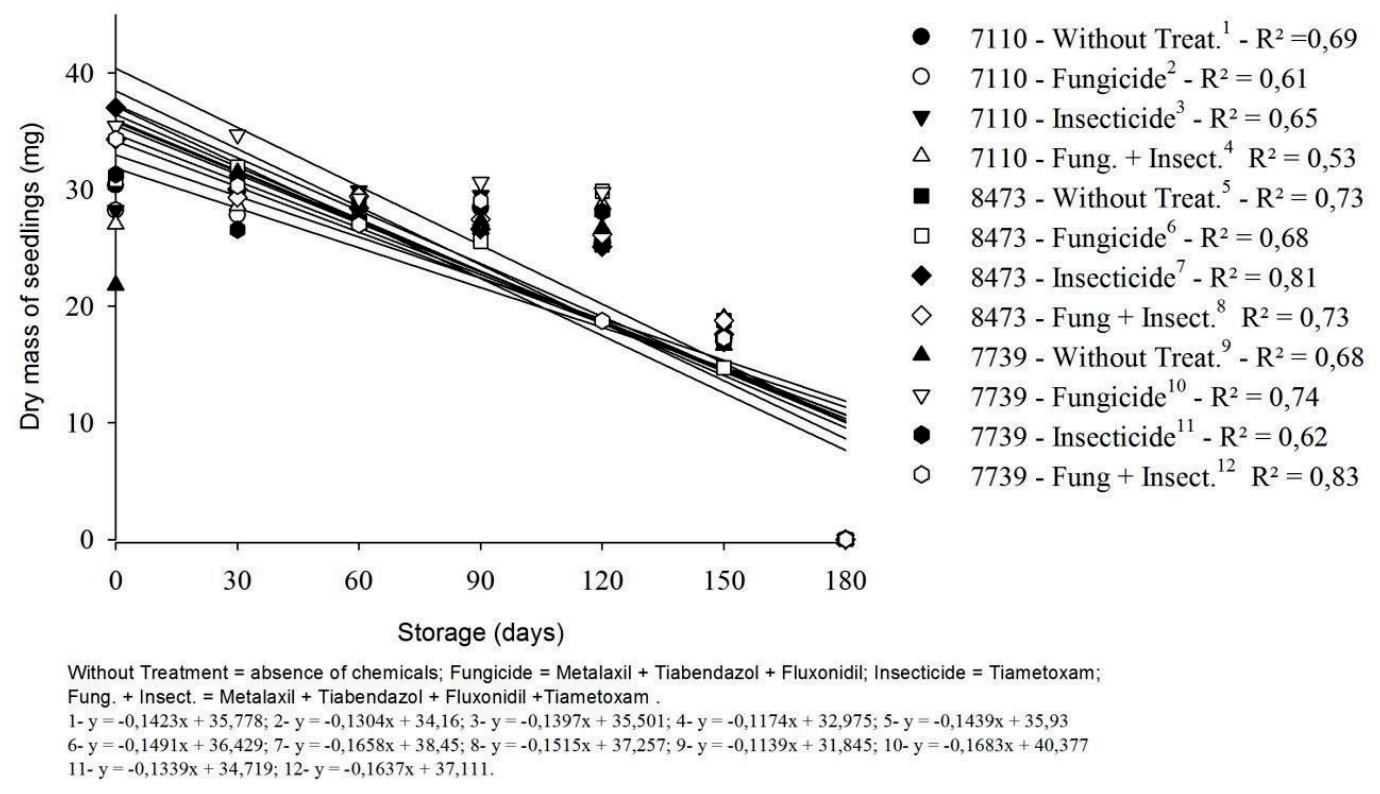

During the analyzed storage period (180 days), the treatments with chemical products applied to the seeds presented higher averages than those of the control (Figure 5), thus indicating that these are beneficial for an increase of the dry mass of seedlings in addition to providing seedlings with larger lengths.

The application of chemicals with the active ingredients thiamethoxam and metalaxyl + thiabendazole + fludioxonil provides soybean seedlings with higher dry mass. Similar results were obtained in a study by Camargo et al. (2017), in which the use of the fungicide metalaxyl + thiabendazole + fludioxonil, combined with the insecticide thiamethoxam, provided larger masses of soybean seedlings.

Segalin et al. (2013) and Dan et al. (2013) did not find that treatment of soybean seeds with different chemical products such as metalaxyl + thiabendazole + fludioxonil and thiamethoxam benefits or harms the seeds during 180 days of storage. Upon analyzing the dry mass of seedlings, the results were consistent with those obtained in this investigation. On the other hand, the results obtained in this study concerning the dry mass of the seedlings diverge from the conclusions of Dan et al. (2010, 2013), affirming that the use of some groups of insecticides such as thiodicarb contributes negatively to the dry mass of soybean seedlings, due to phytotoxic effects.

\section{Conclusions}

The use of the chemicals metalaxyl + thiabendazole + fludioxonil (fungicide), thiamethoxam (insecticide) and their combinations, negatively affects the physiological quality of soybean seeds. Seeds treated alone with metalaxyl + thiabendazole + fludioxonil (fungicide) orthiamethoxam (insecticide), can be stored for 60 days for commercial purposes. The use of thiamethoxamon the cultivar RR-8473 favors seedlings with longer lengths. The effects of the chemicals and the physiological quality of the soybean seeds are reduced throughout storage, and regardless of the genetic material cultivated, the combination of doses of chemicals causes greater physiological damage to soybean seeds. 


\section{Acknowledgments}

The State University of Goiás (UEG), for the funding of the research through Pro-Project Research 029/2016from PrP / UEG. The National Council of Scientific and Technological Development (CNPq), for granting the productivity grant in research to the fourth author.

\section{References}

AVELAR, S. A. G.; BAUDET, L.; PESKE, S. T.; LUDWIG, M. P.; RIGO, G. A.; CRIZEL, R. L.; OLIVEIRA, S. Armazenamento de sementes de soja tratadas com fungicida, inseticida e micronutrientes e recobertas com polímeros líquidos e em pó. Ciência Rural, Santa Maria, v. 41, n. 10, p. 1719-1725, 2011. DOI: $10.1590 / \mathrm{S} 0103-84782011005000130$

BALARDIN, R. S.; SILVA, F. D. L.; DEBONA, D.; CORTE, G. D.; FAVERA, D. D.; TORMEN, N. R. Tratamento de sementes com fungicidas e inseticidas como redutores dos efeitos do estresse hídrico em plantas de soja. Ciência Rural, Santa Maria, v. 41, n. 7, p. 11201126, 2011. DOI: 10.1590/S0103-84782011000700002

BINSFELD, J. A.; BARBIERI, A. P. C.; HUTH, C.; CABRERA, I. C.; HENNING, L. M. M. Uso de bioativador, bioestimulante e complexo de nutrientes em sementes de soja. Pesquisa Agropecuária Tropical, Goiânia, v. 44, n. 1, p. 88-94, 2014. DOI: 10.1590/S198340632014000100010

BRASIL. Ministério da Agricultura, Pecuária e Abastecimento. Regras para análise de sementes. Ministério da Agricultura, Pecuária e Abastecimento. Secretaria de Defesa Agropecuária. Brasília: Mapa/ACS, 2009. $399 \mathrm{p}$.

BRZEZINSKI, C. R.; ABATI, J.; HENNING, F. A.; HENNING, A. A.; FRANÇA-NETO, J. B.; KRZYZANOWSKI, F. C.; ZUCARELI, C. Spray volumes in the industrial treatment on the physiological quality of soybean seeds with different levels of vigor. Journal of Seed Science, Londrina, v. 39, n. 2, p. 174181, 2017. DOI: 10.1590/2317-1545v39n2175179

CAMARGO, F. R. T.; SILVA, I. L.; BARROS, P. J. R.; ASCHERI, D. P. R.; RODOVALHO, R. S. Physiological quality of soybean seeds treated with carboxymethyl cellulose and fungicide. American Journal of Plant Sciences, Hubuwai Province, v. 8, n. 1, p. 2748-2757, 2017. DOI: $10.4236 /$ ajps.2017.811185

CASTRO, G. S. A.; BOGIANI, J. C.; SILVA, M. G.;
GAZOLA, E.; ROSOLEM, C. A. Tratamento de sementes de soja com inseticidas e um bioestimulante. Pesquisa Agropecuária Brasileira, Brasília, v. 43, n. 10, p. 13111318, 2008. DOI: 10.1590/S0100-204X2008001000008

COMPANHIA NACIONAL DE ABASTECIMENTO - CONAB. Grãos: quarto levantamento da safra 2017/2018, março/2018. Brasília: CONAB, 2018. Disponível em: http://www.conab.gov.br/OlalaCMS/ uploads/arquivos/17_04_17_17_20_55_boletim_graos_ abr_2017.pdf. Acesso em: 21 mar. 2018.

CONCEIÇÃO, G. M.; LÚCIO, A. D.; MERTZHENNING, L. M.; HENNING, F. A.; BECHE, M.; ANDRADE, F. F. Physiological and sanitary quality of soybean seeds under different chemical treatments during storage. Agriambi, Campina Grande, v. 20, n. 11, p. 1020-1024, 2016. DOI: 10.1590/1807-1929/agriambi. v20n11p1020-1024

CORADI, P. C.; MILANE, L. V.; CAMILO, L. J.; PRADO, R. L. F.; FERNANDES, T. C. Qualidade de grãos de soja armazenados em baixas temperaturas. Brazilian Journal of Biosystems Engineering, São Paulo, v. 9, n. 3, p. 197-208, 2015. DOI: 10.18011/ bioeng2015v9n3p197-208

CUNHA, R. P.; CORREA, M. F.; SCHUCH, L. O. B.; OLIVEIRA, R. C.; ABREU JUNIOR, J. S.; SILVA, J. D. G.; ALMEIDA, T. L. Diferentes tratamentos de sementes sobre o desenvolvimento de plantas de soja. Ciência Rural, Santa Maria, v. 45, n. 10, p. 1761-1767, 2015. DOI: $10.1590 / 0103-8478 \mathrm{cr} 20140742$

DAN, L. G. M.; DAN, H. A.; BARROSO, A. L. L.; BRACCINI, A. L. Qualidade fisiológica de sementes de soja tratadas com inseticidas sob efeito do armazenamento. Revista Brasileira de Sementes, Londrina, v. 32, n. 2, p. 131-139, 2010. DOI: 10.1590/ S0101-31222010000200016

DAN, L. G. M.; DAN, H. A.; BRACCINI, A. L.; BARROSO, A. L. L. Physiological potential of soybean seeds treated with thiamethoxam and submitted to storage. Agricultural Sciences, Milan, v. 4, n. 11, p. 1925, 2013. DOI: $10.4236 /$ as.2013.411A003

FERREIRA, D. F. Sisvar: a computer statistical analysis system. Ciência e Agrotecnologia, Lavras, v. 35 , n. 6 , p. $1039-1042$, 2014. DOI: $10.1590 / \mathrm{S} 1413-$ 70542011000600001

FERREIRA, T. F. Qualidade de sementes de soja tratadas com inseticidas e fungicidas antes e após $o$ armazenamento. 2016. Dissertação (Mestrado em Agronomia/Fitotecnia) - Universidade Estadual de Londrina, Londrina. 
FREITAS, M. C. M. A cultura da soja no Brasil: o crescimento da produção brasileira e o surgimento de uma nova fronteira agrícola. Enciclopédia Biosfera, Centro Cientifico Conhecer, Goiânia, v. 7, n. 12, p. 1-12, 2011.

LAUXEN, L. R.; VILLELA, F. A.; SOARES, R. C. Desempenho fisiológico de sementes de algodoeiro tratadas com tiametoxam. Revista Brasileira de Sementes, Londrina, v. 32, n. 3, p. 61-68, 2010.

LUDWIG, M. P.; OLIVEIRA, S.; AVELAR, S. A. G.; ROSA, M. P.; LUCCA FILHO, O. A..; CRIZEL, R. L. Storage of treated soybeans and their effect on seedling performance. Tecnologia e Ciência Agropecuária, João Pessoa, v. 9, n. 1, p. 51-56, 2015. http://revistatca. pb.gov.br/edicoes/volume-09-2015/volume-9-numero-1marco-2015/tca9110.pdf.

LUDWIG, M. P.; LUCCA FILHO, O. A.; BAUDET, L.; DUTRA, L. M. C.; AVELAR, S. A. G.; CRIZEL, R. L. Qualidade de sementes de soja armazenadas após recobrimento com aminoácido, polímero, fungicida e inseticida. Revista Brasileira de Sementes, Londrina, v. 33, n. 3, p. 395-406, 2011. DOI: 10.1590/S010131222011000300002

MAVAIEIE, D. P. R. Desempenho de sementes de soja tratadas e não tratadas armazenadas em diferentes condições. Dissertação (Mestrado em Fitotecnia) Universidade Federal de Lavras, Lavras.

MBOFUNG, G. C. Y.; GOGGI, A. S.; LEANDRO, L. F. S.; MULLEN, R. E. Effects of storage temperature and humidity on viability and vigor of treated soybean seeds. Crop Science, New York, v. 53, n. 5, p. 1086-1095, 2013. DOI: $10.2135 /$ cropsci2012.09.0530
MENTEN, J. O. M.; MORAES, M. H. D. Tratamento de sementes: histórico, tipos, características e benefícios. Informativo Abrates, Londrina, v. 20, n. 3, p. 52-55, 2010.

NAKAGAWA, J. Testes de vigor baseados no desempenho das plântulas. In: KRZYZANOWSKI, F. C.; VIEIRA, R. D.; FRANÇA NETO, J. B. (Ed.). Vigor de sementes: conceitos e testes. Londrina: ABRATES, 1999. p. 1-24.

PICCININ, G. G.; BRACCINI, A. L.; DAN, L. G. M.; LIMA, L. H. S. Influência do armazenamento na qualidade fisiológica de sementes de soja tratadas com inseticidas. Ambiência Guarapuava, Maringá, v. 9, n. 2, p. 289-298, 2013. DOI: 10.5777/ambiencia.2013.02.04.

SEGALIN, S. R.; BARBIERI, A. P. P.; HUTH, C.; BECHE, M.; MATTIONI, N. M.; MERTZ, L. M. Physiological quality of soybean seeds treated with diferente spray volumes. Journal of Seed Science, Maringá, v. 35, n. 4, p. 501-509, 2013. DOI: 10.1590/ S2317-15372013000400012

SILVA, J. B.; LAZARINI, E.; SÁ, M. E. Comportamento de sementes de cultivares de soja, submetidos a diferentes períodos de envelhecimento acelerado. Bioscience Journal, Uberlândia, v. 26, n. 5, p. 755-762, 2010.

VIEIRA, B. G. T. L.; BARBOSA, R. M.; TREVISOLI, S. H. U.; Di MAURO, A. O.; VIEIRA, R. D. Biochemical alterations in soybean seeds with harvesting time and storage temperature. International Journal of Food, Agriculture and Enviroment, Helsink, v. 11, n. 3, p. 887 891, 2013. 